\title{
Sensory Profile and Chemical Composition of Specialty Coffees from Matas de Minas Gerais, Brazil
}

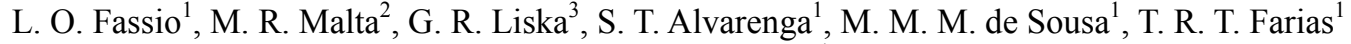 \\ \& R. G. F. A. Pereira ${ }^{1}$ \\ ${ }^{1}$ Food Science Department, Federal University of Lavras, Lavras, Brazil \\ ${ }^{2}$ Coffee Science, Empresa de Pesquisa Agropecuária de Minas Gerais, Lavras, Brazil \\ ${ }^{3}$ Exact Science Department, Federal University of Pampa, Itaqui, Brazil \\ Correspondence: R. G. F. A. Pereira, Food Science Department, Federal University of Lavras, Lavras, Brazil. Tel: \\ 55-35-3829-1402. E-mail: rosegfap@dca.ufla.br
}

Received: June 4, 2017

Accepted: July 5, $2017 \quad$ Online Published: August 15, 2017

doi:10.5539/jas.v9n9p78

URL: https://doi.org/10.5539/jas.v9n9p78

The research is financed by Consórcio Pesquisa Café, FAPEMIG, CAPES and CNPQ.

\begin{abstract}
The aim of this work was to evaluate the sensory profile of specialty coffees, natural and pulped, from the region of Matas de Minas in the State of Minas Gerais, Brazil and correlate the sensory scores with the chemical composition of the grains. Twenty samples of Arabica coffee were assessed (10 Natural and 10 Pulped), as the sensory profile (Cup of Excellence) and sucrose content, bioactive compounds and fatty acids of raw beans. The processed pulped coffees stood out as the final scores. The attributes sweetness, acidity and flavor were important for the distinction of the pulped coffees, while natural coffees the determining attributes were body and acidity. The bioactive compounds and sucrose showed positive and negative correlation with the sensory attributes, respectively. The acids $\mathrm{C} 14: 0, \mathrm{C} 18: 2$ and $\mathrm{C} 18: 3$, were relevant to the sensory distinction of natural coffees. The acids C18:0 and C20:2 showed positive correlation, and acids C18:2 and C18:3, negative, with the sensory attributes of the pulped coffees. The specialty coffees of the region of Matas de Minas feature distinct sensory profiles and it is possible to correlate them with the chemical composition of the grains.
\end{abstract}

Keywords: sensory attributes, coffee quality, post-harvest, multivariate analysis

\section{Introduction}

Coffee is the second most consumed beverage in the world, preceded only by water. This high consumption is due not only to the pharmacological functions produced by caffeine content and antioxidant compounds present in the drink, which beneficially influence human health, but also and mainly to the characteristic flavor of the product. The flavor and aroma of coffee are the most important features for the final quality of the drink, which depends on the chemical composition of the grains, influenced by genetic factors, environmental, agricultural, harvesting and post-harvest practices, storage, toasting and preparation methods (Alves et al., 2011; Borém et al., 2008; Mendonça et al, 2009).

With the advent of specialty coffee segment quality assessment methodologies have been enhanced with the quantification of attributes of the drink (taste, aroma, acidity, body, sweetness, clean drink, absence of flaws, balance, and finalization) for better characterization to the perceived nuances, and therefore, greater product differentiation (SCAA, 2015). In this sense, many works have been developed to understand the complexity that exists in the production of specialty coffees with specific and unique attributes (Borém et al., 2016; Silveira et al., 2016; Carvalho et al., 2016; Fassio et al., 2016; Figueiredo et al., 2015; Silva et al., 2014; Sunarharum et al., 2014; Scholz et al., 2013; Bertrand et al., 2006; Avelino et al., 2005). A method that has excelled as effective in research with specialty coffees is the use of statistical tools such as Principal Component Analysis, the Method of Content Analysis, the Decision Tree by Hierarchical Cluster Analysis by CHAID method, Artificial Neural Networks, Discriminant Analysis by Boosting method, among others, all featuring the most secure and reliable information about the quality of the coffee drink (Ramos et al., 2016; Sobreira et al., 2015; Ribeiro et al., 2016; Liska et al., 2015; DonFrancesco et al., 2014; Link et al., 2014). 
As for the wine (Morlat \& Bodin, 2006), the coffee is considered a product of terroir, i.e., its quality is directly related to soil and climate conditions where it is cultivated (Piccino et al., 2014; Silva et al., 2014) and the differentiation of cafes through this principle makes it possible to determine potential areas to produce specialty coffees and to characterize the type of coffee from these areas, exploring their potentialities (Silva et al., 2014). The region of Matas de Minas is in the State of Minas Gerais is one of many Brazilian regions with potential for production of better quality coffees. The region of Matas de Minas englobes the areas in the parallels $40^{\circ} 50^{\prime}$ to $43^{\circ} 36^{\prime}$ latitude $\mathrm{S}$ and $18^{\circ} 35^{\prime}$ to $21^{\circ} 26^{\prime}$ longitude $\mathrm{W}$, and is characterized as mountainous at altitudes ranging between 600 and 1,200 meters and covers much of the northern portion of the geographic region of Zona da Mata of Minas Gerais and small part of the southern portion of the Vale do Rio Doce (Silveira et al., 2016; Ferreira et al., 2016; Scolforo et al., 2007). It is considered a producing source of quality coffees, situated in an area of Atlantic forest, with naturally sustainable production, marked by the predominance of family agriculture, by the direct and indirect economic and social impact, natural integration between man and forest, and cultural factors present in coffee production in the region. The result of the craftsmanship developed in this region are coffees with diversity of nuances and different flavors, that has been excelling in the specialty coffee market.

In this context, the objective of this work was to characterize the sensory profile of specialty coffee samples from the region of Matas de Minas, and by Principal Component Analysis plot correlation between the sensory attributes and the chemical composition of the grains.

\section{Method}

Twenty samples of special coffee were selected (Coffea arabica L.) from the region of Matas de Minas, and of this total, 10 samples from the "wet process - Pulped Coffee" category and 10 from the "dry process - Natural Coffee". The samples were selected randomly from the result of the $10^{\text {th }}$ Quality Contest of Minas Gerais.

The encoding, the municipality, the form of processing and final grade for each of the samples are shown in Table 1.

Table 1. Municipality and processing of twenty specialty coffees from Matas de Minas, Brazil

\begin{tabular}{llll}
\hline Sample Codes & Municipality & Processing & Final Score \\
\hline $01 \mathrm{CD}$ & Espera Feliz & Pulped & 84.92 \\
$02 \mathrm{CD}$ & Espera Feliz & Pulped & 82.58 \\
$03 \mathrm{CD}$ & Manhuaçu & Pulped & 83.08 \\
$04 \mathrm{CD}$ & Araponga & Pulped & 83.67 \\
$05 \mathrm{CD}$ & Espera Feliz & Pulped & 86 \\
$06 \mathrm{CD}$ & Espera Feliz & Pulped & 86.6 \\
$07 \mathrm{CD}$ & Espera Feliz & Pulped & 85.5 \\
$08 \mathrm{CD}$ & Espera Feliz & Pulped & 83.6 \\
$09 \mathrm{CD}$ & Espera Feliz & Pulped & 83.4 \\
$10 \mathrm{CD}$ & Mutum & Pulped & 82 \\
$11 \mathrm{NAT}$ & Ervália & Natural & 83.82 \\
$12 \mathrm{NAT}$ & Espera Feliz & Natural & 83.45 \\
$13 \mathrm{NAT}$ & Manhuaçu & Natural & 82.8 \\
$14 \mathrm{NAT}$ & Santa Margarida & Natural & 82.73 \\
$15 \mathrm{NAT}$ & Araponga & Natural & 82.64 \\
$16 \mathrm{NAT}$ & Manhuaçu & Natural & 82.27 \\
$17 \mathrm{NAT}$ & Espera Feliz & Natural & 81.72 \\
$18 \mathrm{NAT}$ & Santa Margarida & Natural & 81.36 \\
$19 \mathrm{NAT}$ & Manhuaçu & Natural & 81.27 \\
$20 \mathrm{NAT}$ & Araponga & Natural & 80.54 \\
\hline & & &
\end{tabular}

\subsection{Sensory Analysis}

The Sensory analysis was developed during the $10^{\text {th }}$ Quality Contest of Minas Gerais, held in the Center of Technology and Quality of Coffee at the Universidade Federal de Lavras, using the Cup of Excellence - CoE methodology adopted by the Brazilian specialty coffee Association (BSCA, 2016). Fourteen trained tasters 
evaluated five cups of each sample as the following attributes: clean drink, sweetness, acidity, body, flavor, aftertaste, balance, overall quality and final score. The coffees that have scored 80 points or more were classified as specialty coffees. The attributes sweetness, flavor, aroma, body and final score, were statistically analyzed, because these are the main responsible for the distinction of different sensory profiles of coffee.

\subsection{Sample Preparation}

The samples were placed in paper coated with polyethylene packing, and stored in cold chamber to $16{ }^{\circ} \mathrm{C}$ after the sensory rating. For performing chemical analysis, samples of raw beans were milled into sample mill IKA® A11basic for about 1 minute with the addition of liquid nitrogen to make it easier to grind and avoid the oxidation of the samples. The following were placed in falcon pipes and stored in freezer, at temperature of $-20{ }^{\circ} \mathrm{C}$, until the completion of the chromatographic analyses.

\subsection{Chromatographic Analysis}

\subsubsection{Caffeine, Trigonelline and cqa-5}

Extraction of bioactive compounds caffeine, chlorogenic acid (cqa-5) and trigonelline has been carried out per the methodology proposed by Malta and Chagas (2009). These compounds were determined simultaneously, using high-performance liquid chromatography (HPLC). The system operated with injection valve Prominence Shimadzu model SIL-20AHT, with fixed loop of $20 \mu 1$ and Shimadzu processor. We used reverse phase column C18 Shim-pack CLC-ODS (M), Shimadzu $(5 \mu \mathrm{m}, 150 \mathrm{~mm} \times 4.6 \mathrm{~mm})$, with pre-column of $4 \mu \mathrm{m}$. Elution was isocratic with mobile phase consisting of methanol:acetic acid:water $(25: 0.5: 74.5)$, flow rate of $1 \mathrm{~mL} / \mathrm{min}$, at $30{ }^{\circ} \mathrm{C}$.

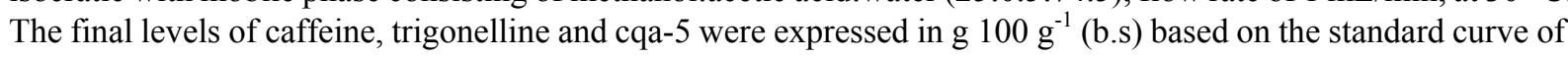
each compound reviewed

\subsubsection{Sucrose}

It was followed the proposed by Murkovic and Derler (2006) for analysis of sucrose. The Liquid Chromatograph used consisted of a pump LC-10AD (Shimadzu), Refractive Index detector RID-10A (Shimadzu), Rheodyne injection valve and Star data acquisition system 5.5 (Varian). The samples and standards solutions were analyzed in 2 columns in series: Nucleosil C18-5 $\mu \mathrm{m} 250 \mathrm{~mm} \times 4 \mathrm{~mm}$ (Supelco) and Discovery HS F5 $150 \mathrm{~mm} \times 4 \mathrm{~mm}$ (Supelco). The mobile phase was Milli-Q water at room temperature and flow of $1.0 \mathrm{~mL} / \mathrm{min}$ and $20 \mu \mathrm{L}$ of injection volume. The final content of sucrose was expressed in $\mathrm{g} 100 \mathrm{~g}^{-1}$ (b.s.) based on standard curve of sucrose.

\subsubsection{Fatty Acids}

The fatty acids were extracted from samples Folch et al. (1957). The analyses were conducted on gas chromatograph model GC-17 A Flame Detector (FID) (Shimadzu). For registration and analysis of Chromatograms, the appliance is connected to a computer, using the program GC Solution. The compounds were separated and identified on a Carbowax capillary column $(30 \mathrm{~m} \times 0.25 \mathrm{~mm})$ in Split System $=5$, and nitrogen gas with linear speed programmed to $37.8 \mathrm{~cm} / \mathrm{s}$. The injector and detector temperatures were isothermally controlled at $220{ }^{\circ} \mathrm{C}$ and $240{ }^{\circ} \mathrm{C}$. The initial temperature of the column was to $200{ }^{\circ} \mathrm{C}$ (maintained by 2 minutes), increase by $4{ }^{\circ} \mathrm{C}$ per minute until it reached $240{ }^{\circ} \mathrm{C}$ for a total of 20 minutes of analysis. The gas flow of drag in column was of $1.0 \mathrm{~mL} /$ minute. The identification of the compounds was performed through the retention time of the corresponding standard and contents of each fatty acid has been expressed in $\mathrm{g} 100 \mathrm{~g}^{-1}$ (b.s.).

\subsection{Data Analysis}

The sensory profile of the samples was analyzed in a simple diagram named Sensograma (Sobreira et al., 2015) considering the average value of the total scores and sensory attributes for samples of each type of processing, using the tasters as repetition.

The data were subjected to multivariate analysis to better understand the relationship between the sensory scores and the chemical compounds evaluated. We used the Principal Component Analysis (PCA) to the breakdown of samples, resulting in the grouping of points according to sensory scores and chemical variables. For this analysis, the statistical software R (R Development Core Team, 2016) was used.

\section{Results and Discussion}

\subsection{Sensory Profile of Pulped Coffees (CD) and Natural Coffees (NAT)}

The range of final score between the pulped coffees was high, ranging from 82 points to 86.6 points, even the samples in this category being mostly from the same municipality, i.e., Espera Feliz (Table 1). This observation can be corroborated by the research of Silva et al. (2016), in which it was evaluated the influence of climatic conditions in the region of Matas de Minas on the quality of the coffees of 20 municipalities in the region, in 
which the authors concluded that even in the same or similar climatic conditions the samples presented different scores for the quality of the drink.

The range of final score for the category natural coffees was from 80.5 to 83.8 (Table 1) ranging up to 3 points on the scale, which showed, therefore, uniformity for the final score among the coffees of this category. It is known that several factors influence the quality of the coffee drink, among them are the genotype, environment, processing, drying, storage, the toasting process and method of preparation (Carvalho et al., 2011; Alves et al., 2011; Clemente et al., 2015; Malta et al., 2013; Abreu et al., 2015; Ribeiro et al., 2009). Therefore, each isolated factor or interaction between them can provide the coffee different sensory profiles, resulting in no repetition of harvest, in both qualitative and quantitative aspect. The region of Matas de Minas was known for many years as a producer of low-quality natural coffees, mainly due to the accumulation of moisture and high temperature at sowing and drying, factors that contribute to fermentation processes that affect the quality of the product (Campanha et al., 2007; Barbosa et al., 2010). With the adoption and diffusion of new technologies for the processing and drying of coffee, many producers would adhere to the wet processing to improve the quality of the coffee.

Coffees with the same final score often show distinct scores for specific quality attributes (Sobreira et al., 2015). To analyze the balance of the scores of the sensory attributes of the samples we used Sensogramas in a graphical projection (Figure 1).

Cherry pulped coffee (Figure 1a), for the most part, are more balanced in scores of the sensory attributes. In General, the 06CD stood out from other coffees as compared to attributes sweetness (6.6), acidity (6.7) and clean drink (6.5), flavor and body attributes presented equal scores (6.2), the remaining attributes presented scores below 6.0. By contrast, the 10CD presented the lower scores of the sensory attributes evaluated with grades below 5.8, except to clean drink (6.0). In this case, it is important to notice that even the sample showing a clear drink in the cup, or without flaws, not necessarily the same will stand out compared to other attributes. The other samples showed very similar scores for all attributes. With these results, it should be noted that balanced and higher scores for the main attributes of the drink, sweetness, acidity and flavor, influenced positively on final score of pulped natural coffee drink of the region of Matas de Minas Gerais.

For the natural category (Figure 1b), notice that the sensory attributes scores are closer (most between 5.8-6.0) for most samples, overlapping the lines, except for three samples that presented the scores of sweetness, flavor, acidity and body out of the average. The 18NAT sample stood out with higher scores to the attributes sweetness (6.5), acidity (6.3) and flavor (6.5). The sample 16NAT presented the lowest values for the scores of acidity and body (5.8 and 5.6 respectively), the sample 12 NAT presented the lowest value for the attribute sweetness (5.69), and the sample 13NAT the lowest value for the flavor (5.7), followed by the 15NAT samples (5.8) and 17NAT (5.8). The body attribute was more pronounced in samples of natural coffee, mainly in the 15NAT samples (6.4) and 20NAT (6.4).

The score of the main sensory attributes of the quality of the drink (sweetness, acidity, flavor and body) were not the highest for the 11NAT sample. However, this sample presented similar scores for all attributes (average 6.0 points), a very valued feature in the market of specialty coffees, and maybe for this reason it obtained the best score in the natural category. Sobreira et al. (2015) observed that the scores of sensory attributes behave differently within groups of genotypes with similar or equal total scores also using "Sensograma". 

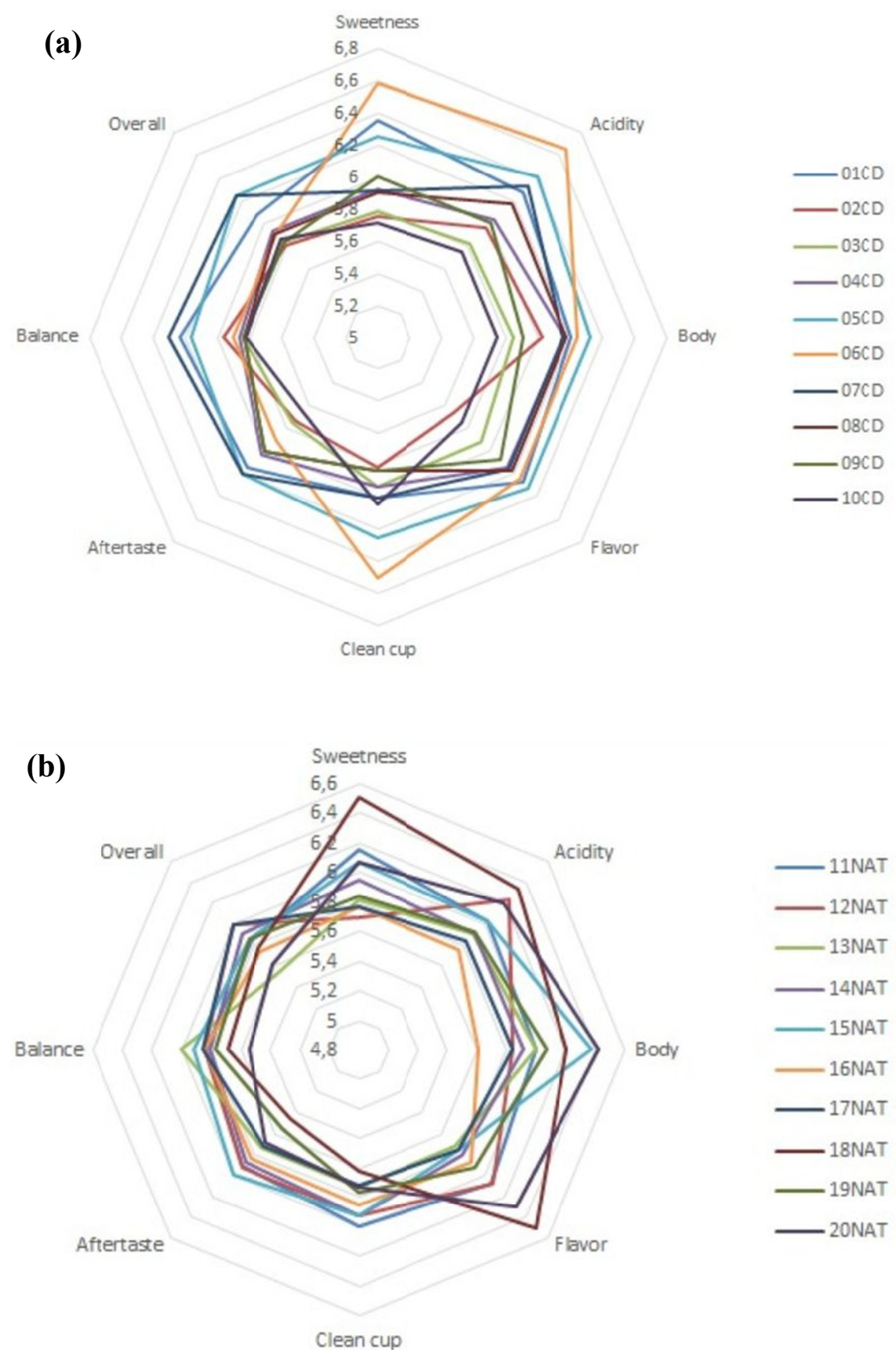

Figure 1. Sensograma of the average values of the scores of the sensory attributes of fourteen tasters to the Pulped (a) and Natural category (b)

\subsection{PCA of the Sensory Attributes, Bioactive Compounds and Sucrose for Pulped and Natural}

The average values in $\mathrm{g} 100 \mathrm{~g}^{-1}$, minimum and maximum obtained for caffeine compounds (1.26-1.49), trigonelline (0.99-1.22), cqa-5 (4.50-5.05) and sucrose (5.25-7.86) of the pulped coffees, and caffeine (1.27-1.47), trigonelline (1.04-1.26), cqa-5 (2.32-5.29) and sucrose (6.11-7.26) for natural coffees are in the range expected for raw beans of Arabica coffee (Farah et al., 2006; Franca et al., 2005; Figueiredo et al., 2013; Borém et al., 2016).

Figure 2a is a graphical representation of the results obtained from the PCA for the distribution of the pulped samples $(\mathrm{CD})$ in function of the sensory scores and caffeine compounds, trigonelline, cqa-5 and sucrose, and Figure $2 \mathrm{~b}$ is the graphical representation of the groups formed. The two first principal components explain $71.98 \%$ of the variability of responses. The sensory attributes and the final score were instrumental in the 
formation of the PC1, and trigonelline compounds, cqa-5 and sucrose to the PC2. The caffeine parameter presented almost no explanation to the PC2 not being important for the explanation of this analysis (Table 2). Studies from Fassio et al. (2016), Figueiredo et al. (2013), Barbosa et al. (2012), and Avelino et al. (2005) also could not correlate directly the content of caffeine in drink quality in specialty coffees. However, Franca et al. (2005), and Farah et al. (2006), assessed the relation of caffeine with coffees of different sensory classes and found positive correlation between higher levels of caffeine in raw beans of Arabica coffee with the quality of drink. Therefore, caffeine is not a satisfactory parameter for evaluation of specialty coffees.

Thus, through correlation scores (Table 2) and the dispersion of the points in Figure 2b, it is possible to identify that the coffees allocated in the groups I and III, are the coffees with higher sensory scores and coffees allocated in Group II present intermediate and low sensory scores. Correlating this information with the composition of the coffees in trigonelline, cqa-5 and sucrose levels, it was possible to notice that there are coffees with high values of trigonelline and cqa-5 and low sucrose, and coffees with high values of sucrose and low trigonelline and cqa-5, within the three groups of samples. Therefore, for these specialty coffees, higher sensory scores correlate positively with sucrose, which is the case of the $06 \mathrm{CD}$ and $05 \mathrm{CD}$ coffees, and also with trigonelline and cqa-5 $(01 \mathrm{CD}$ and $07 \mathrm{CD})$, and the same occurred to the coffees of Group II. These results demonstrate the existing variability for chemical composition and quality of drink.

In the literature, it is exposed that higher sensory scores coffees correlate positively with the sucrose and trigonelline contents, and there is no satisfactory correlation with the phenolic compounds, such as chlorogenic acid and its isomers (Malta \& Chagas, 2009; Barbosa et al., 2012; Mendonça et al., 2009; Bertrand et al., 2006; Farah et al., 2006; Figueiredo et al., 2013; Fassio et al., 2016; Borém et al., 2016). The trigonelline is an important precursor of volatile compounds that contribute to the desirable taste and aroma of roasted coffee, as well as the formation of chlorogenic acid taste astringent. Even in low concentrations, the impact of the chlorogenic acid in quality may be relevant, and lower levels of chlorogenic acids are associated with better quality of coffee drink (Perrone et al., 2012). There is not yet a right relationship that the sucrose content in raw beans of Arabica coffee is directly related to the quality of the drink, because it suffers considerable variation per species, variety and geographic origin (Knopp et al., 2006, Oosterveld et al., 2003). However, some studies are already achieving significant results in this correlation, since in the toasting process it is degraded to compounds relevant to the flavor and aroma of coffee. Ina study of Borém et al. (2016) the authors observed that the sucrose content could discriminate specialty coffee genotypes in separate groups per score, and the coffees with higher sensory scores correlated positively with sucrose. The same was observed by Bertrand et al. (2003) and Decazy et al. (2003).

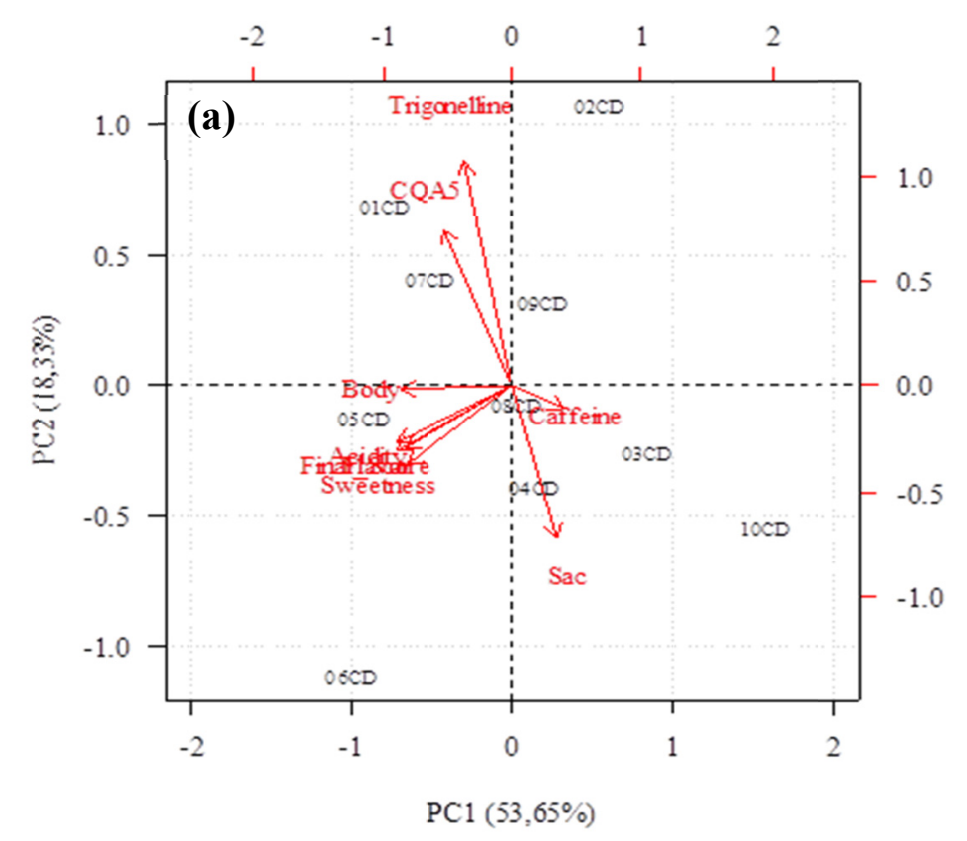




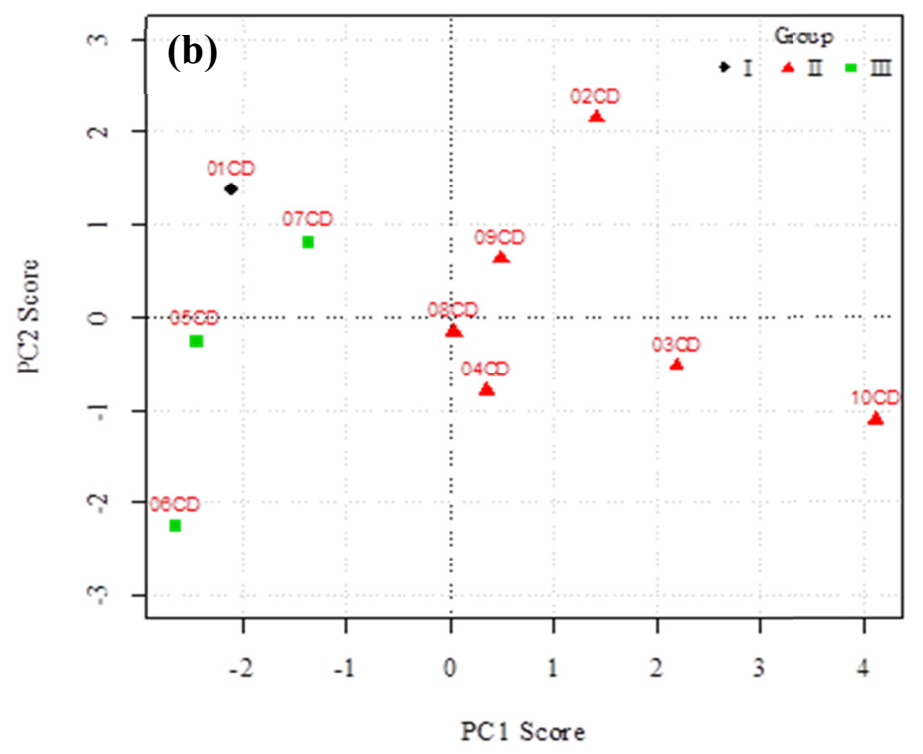

Figure 2. Biplot of the two first principal components (a) and groupings (b) to data of ten samples of pulped coffee, in function of the sensory scores and trigonelline, cqa-5, caffeine and sucrose compounds. $\mathrm{CD}=$ Pulped

For the category, natural coffees, the two first principal components explained $63.63 \%$ of the total variability of responses (Figure 3a). Figure 3b shows the separation of the groups formed from the dispersion of the points in the document, being possible to identify distinct groups of 3 samples.

The sensory attributes sweetness, acidity, body and flavor were instrumental in the formation of the PC1, and the sweetness, acidity and flavor attributes were responsible for separation of 18NAT coffees in Group II and the body attribute for the separation of the 20NAT coffee in Group III (Figure $3 \mathrm{~b}$ and Table 2). The first main component also explained that the cqa-5 and sucrose correlate with the score of sensory attributes of natural coffees, however negatively. Soon, it was possible to confirm the proposed in the literature as to the negative correlation between the content of chlorogenic acid and the scores of the sensory attributes (Mendonça et al., 2009; Bertrand et al., 2006; Figueiredo et al., 20013; Fassio et al., 2016) but again it was not possible to correlate the contents of sucrose with the sensory attributes. Therefore, it is observed that the joint analysis of the data of bioactive compounds and sucrose for correlation with sensory scores values are not fully explanatory, indicating the possibility of studies with these variables separately.

The chemical compounds, along with the body, were the main parameters responsible for the formation of the PC2. There was the formation of two pairs of variables, the first couple (trigonelline and sucrose) influencing positively in the body of the drink and the second pair (cqa-5 and caffeine) negatively influencing the body attribute (Table 2). Borém et al. (2016) also observed the body being an important attribute to discriminate the sensory profile of samples of coffees with lower sensory score. The 20NAT sample of Group III, was the coffee that showed the highest score to body and consequently higher levels of trigonelline and sucrose and less of cqa-5 and caffeine, while the reverse was observed for the coffee 12NAT in Group I that presented low value for body and higher levels of cqa-5 and caffeine, and lower scores of sucrose and trigonelline (Figure $3 \mathrm{~b}$ and Table 2). The body of the coffee drink is an attribute that is used to describe the physical, texture and density properties (Lingle, 2011; Illy \& Viani, 2005). Carbohydrates play an important role in the perceived viscosity on coffee drink, the polysaccharides such as cellulose, arabinogalactan, and mannans contribute more substantially, and in a lesser proportion the carbohydrate glucose, fructose and sucrose (Buffo \& Cardeli-Freire, 2004). In this way, one realizes that the sucrose is contributing to the formation of the body, corroborating with the authors cited above. 

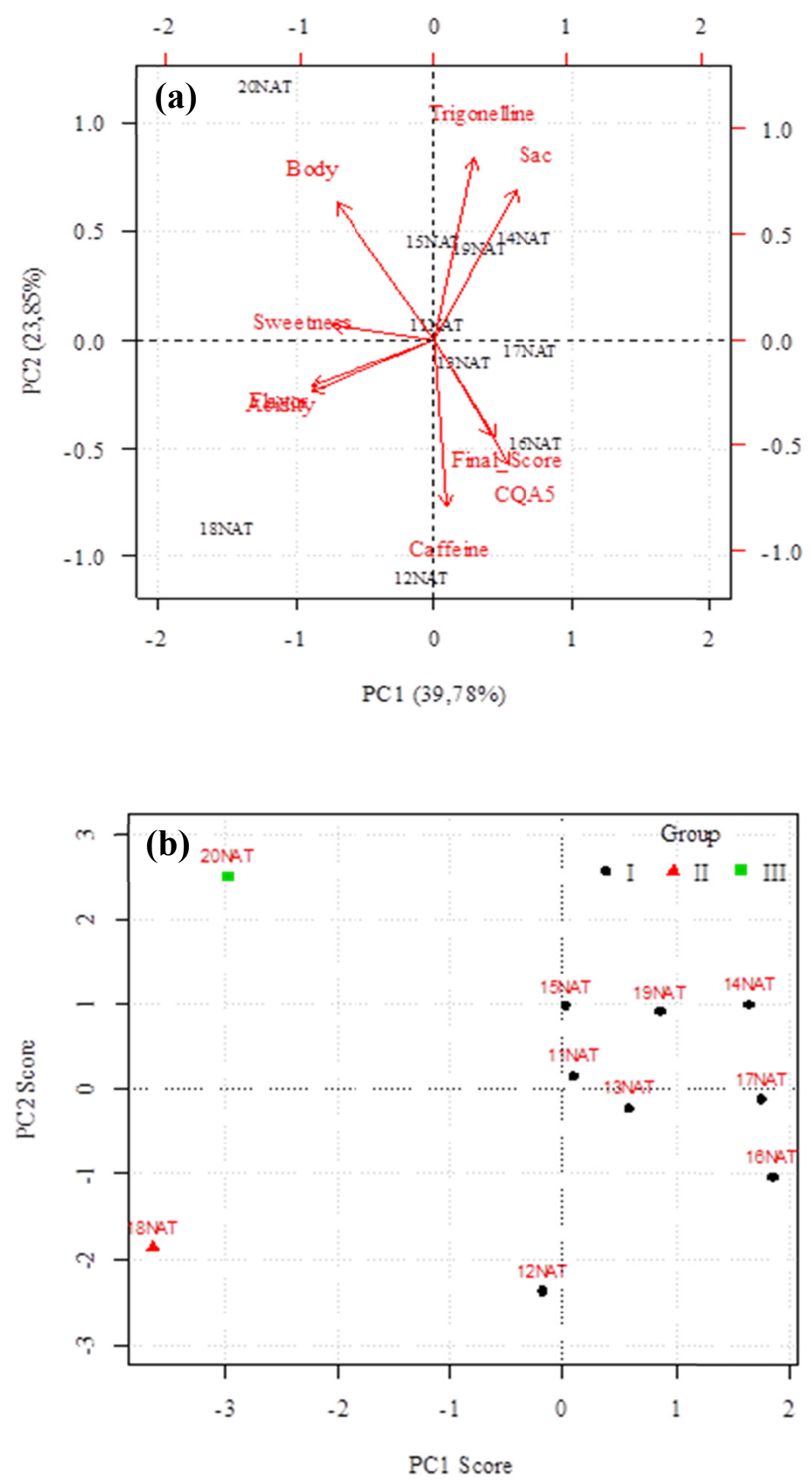

Figure 3. Biplot of the two first principal components (a) and groupings (b) to data of ten samples of Natural coffee, in function of the sensory scores and trigonelline compounds, cqa- 5 , caffeine and sucrose. NAT $=$ Natural 
Table 2. Correlations between the parameters assessed with the first two principal components for pulped coffee and natural coffee

\begin{tabular}{|c|c|c|c|c|}
\hline \multirow{3}{*}{ Parameters } & \multicolumn{2}{|c|}{ Pulped Rank (CD) } & \multicolumn{2}{|c|}{ Natural Rank (NAT) } \\
\hline & $\mathrm{PC} 1$ & PC2 & $\mathrm{PC} 1$ & PC2 \\
\hline & Correlation* & Correlation* & Correlation* & Correlation* \\
\hline Sweetness & -0.85 & -0.29 & -0.75 & -0.75 \\
\hline Acidity & -0.94 & -0.21 & -0.89 & -0.89 \\
\hline Body & -0.91 & -0.01 & -0.70 & -0.70 \\
\hline Flavor & -0.86 & -0.23 & -0.89 & -0.89 \\
\hline Final_Score & -0.93 & -0.24 & 0.43 & 0.43 \\
\hline Trigonelline & -0.39 & 0.84 & 0.28 & 0.28 \\
\hline CQA5 & -0.54 & 0.59 & 0.53 & 0.53 \\
\hline Caffeine & 0.41 & -0.08 & 0.09 & 0.09 \\
\hline $\mathrm{Sac}$ & 0.35 & -0.57 & 0.60 & 0.60 \\
\hline
\end{tabular}

Note. * Variables in bold and italic indicate groups of variables to be formed, characterized by variables whose correlation with the principal component are high and with the same signal.

\subsection{PCA of the Sensory Attributes and the Fatty Acids for Pulped and Natural Coffees}

The average values in $\mathrm{g} 100 \mathrm{~g}^{-1}$, minimum and maximum, obtained for the seven fatty acids found in this study for pulped: C14:0 (1.59-4.81), C16:0 (38.36-40.74) C18:0 (4.31-6.71), C18:1 (5.97-8.18), C18:2 (50.20-56.51), $\mathrm{C} 18: 3$ (0.99-1.27), C20:2 (1.27-2.18), and to natural: C14:0 (2.36-5.43), C16:0 (37.9-40.51), C18:0 (4.81-6.72), C18:1 (6.67-8.12), C18:2 (48.31-54.39), C18:3 (0.91-1.48), C20:2 (1.39-2.55), are situated in the range expected for raw beans of Arabica coffee (Martin et al., 2001; Figueiredo et al., 2015; Bertrand et al., 2008).

As shown in Figure 4a, the two first principal components feature $75.76 \%$ of the total variability of response of the PCA and the formation of 3 groups of samples per the attributes and final score and of the fatty acids found in the pulped coffees (Figure $4 b$ ).

The PC1 has been set from the parameters sweetness, acidity, body, flavor, final score and also by fatty acids C18:0, C18:2, C18:3 and C20:2, which shows that for the coffees of the pulped category, these fatty acids have correlation with the quality of the drink, and the acids C18:0 and C20:2 correlate directly with the scores of the attributes and with the final score of coffees, and were instrumental to group the coffees with higher final scores in groups I and III, while the acids C18:2 and C18:3 showed negative correlation with these characteristics and were instrumental in allocating the coffees with lower final score in Group II (Table 3, Figure 4b).

The contents of lipids found in various natural sources gives the foods distinct flavor profiles by the presence of characteristic volatile compounds, as by-products of lipid oxidation (Damodaram et al., 2007). Fatty acids can contribute to subtle and pleasant scores of flavor and are the main compounds responsible for texture and mouthfeel of the coffee drinks (Oestreich-Janzen, 2010). Corroborating with the present study, Figueiredo et al. (2015) could correlate the contents of four fatty acid (C20:0, C18:1t, C18:0 and C14:0) with the sensory characteristics of specialty coffees, and Fassio (2014) also observed negative correlation between linoleic acid (C18:2) and the sensory attributes of plant varieties of Arabica coffee.

For the formation of the PC2, it is observed that the fatty acids C18:0, C14:0, C18:1, and C20:2, and the acidity showed strong correlation, however the fatty acid C14:0 presents positive correlation and other fatty acids negative correlation. Therefore, these four fatty acids influenced in defining the acidity of coffees of pulped category. From the above and analyzing the Figure 4b, you can see that the fatty acids C18:0, C14:0, C18:1, and $\mathrm{C} 20: 2$ were important for the separation of coffees of lower and intermediate acidity scores $(09 \mathrm{CD}, 10 \mathrm{CD}, 03 \mathrm{CD}$, $08 \mathrm{CD}$ and $02 \mathrm{CD}$ ) within the Group II. It is reported that the lack of balance of flavor in foods is associated with low levels of saturated fatty acids (Banks et al., 2007) and unsaturated fatty acids, due to the ease of suffering oxidation and produce rancid flavor, can collaborate to the decrease of food quality (Jham et al., 2008). In this study, it was observed that both saturated fatty acid (C18:0) and the unsaturated fatty acid (C20:2) are able to discriminate pulped coffees by the sensory scores of the attributes and final score. 

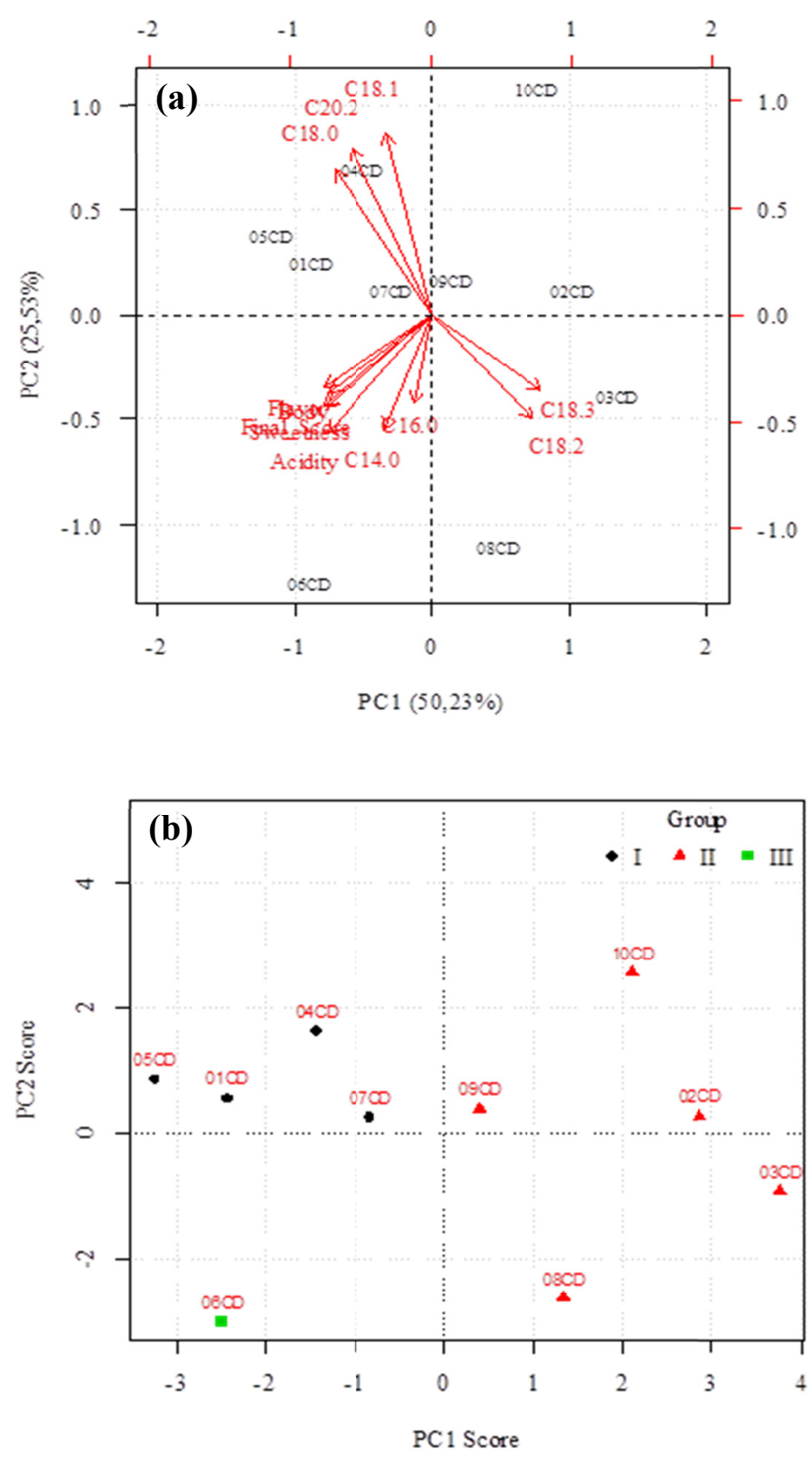

Figure 4. Biplot of the two first principal components (a) and groupings (b) to data of ten samples of Pulped coffee, in function of the sensory scores and of the fatty acids. $\mathrm{CD}=$ Pulped. C14:0 = myristic acid, C16:0 = palmitic acid, C18:0 = stearic acid, C18:1 oleic acid, C18:2 linoleic acid, C18:3 = linolenic acid, C20:2 = arachidonic acid

For the category, natural coffees, the two first principal components showed $60.74 \%$ of the variability (Figure $5 a)$, and there was the separation of the coffee in three distinct groups as shown in Figure $5 \mathrm{~b}$.

The attributes sweetness, acidity, body, flavor and fatty acids C14:0 and C18:0 were instrumental in the formation of the $\mathrm{PC} 1$, however these parameters showed negative correlation for this component, that is, coffees in the natural category from Matas de Minas, with high scores for the sensory attributes present low rates for the fatty acids C14:0 and C18:0. Demonstrating again that the hypothesis of a correlation between saturated fatty acids and sensory quality (Banks et al., 2007; Jham et al., 2008) does not apply to specialty coffees of the region of Matas de Minas, evaluated in this work. For PC2 is possible to observe that the fatty acids C14:0, C18:0, $\mathrm{C} 18: 1, \mathrm{C} 18: 2, \mathrm{C} 18: 3$ and $\mathrm{C} 20: 2$ were instrumental for its formation, and the fatty acids C14:0, C18:2 C18:3 and correlate with each other, and the same is true among the acids C18:0, C18:1, and C20:2 (Table 3). 
It is observed in the Figure $5 \mathrm{~b}$ and by scores of PC1 and PC2 (Table 3) that attributes sweetness, acidity, body and flavor were instrumental in the separation of the sample 18NAT in Group III, along with the fatty acids C14:0, C18:2 and C18:3. These fatty acids can be classified as important for the definition of the sensory attributes of the category Natural coffee. The fatty acids C14:0, C18:0, C18:2 and C18:3 were responsible for the Group II with samples 17NAT and 19NAT, which are coffees with lower sensory attributes. The coffees allocated in Group I can be considered as those which showed correlation with all the fatty acids evaluated in this study. The fatty acid composition of coffee depends on several factors, such as the species, variety, cultivation environment, storage of grain, beverage preparation (Amaral et al., 2006). The content of fatty acids has been shown to be an important tool in the differentiation of specialty coffees, a fact observed in the results obtained by various authors (Avelino et al., 2005; Figueiredo et al., 2015; Bertrand et al., 2008; Fassio, 2014).
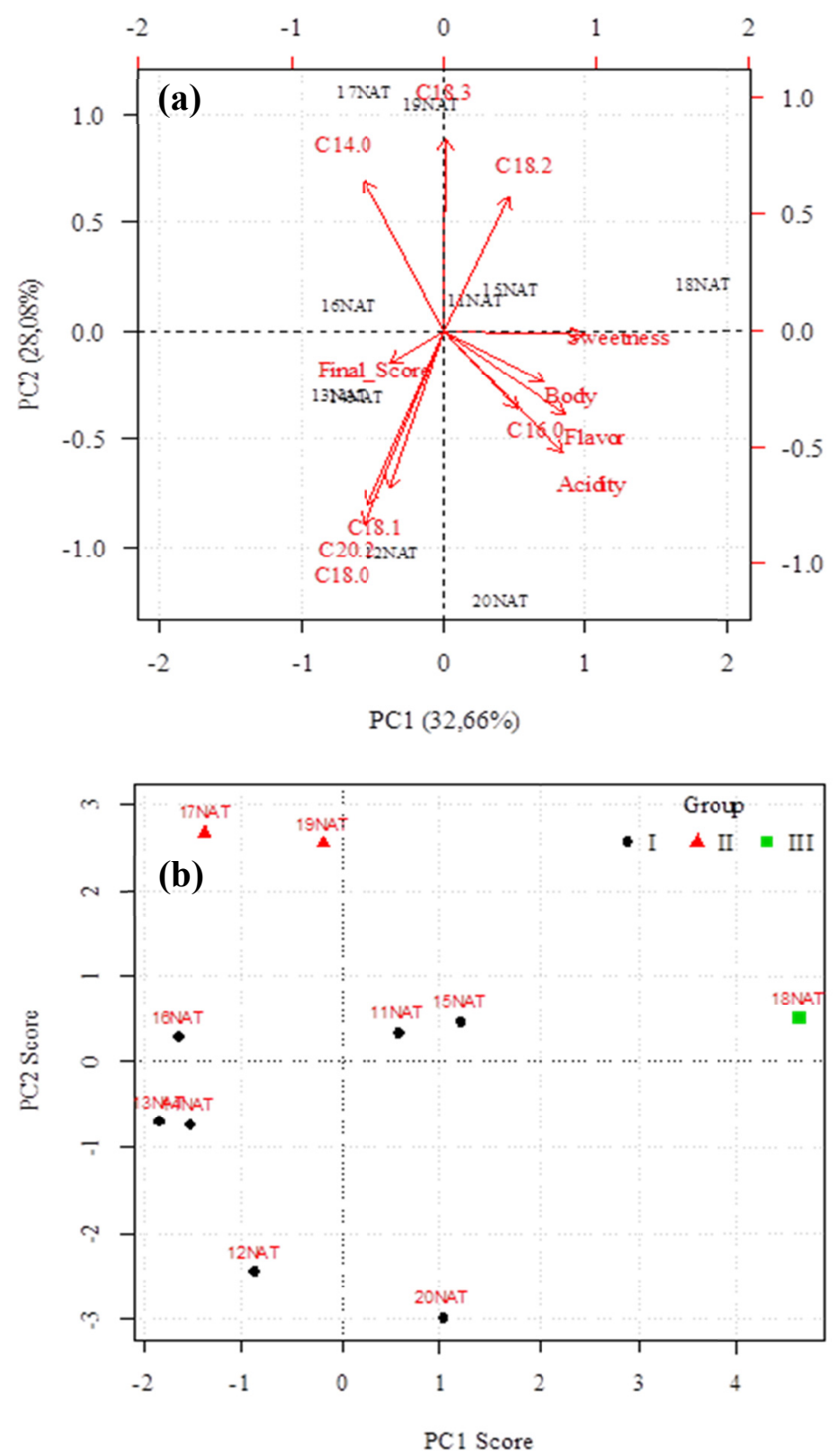

Figure 5. Biplot of the two first principal components (a) and groupings (b) to data of ten samples of Natural coffee, in function of the sensory scores and of the fatty acids. NAT $=$ Natural. C14:0 $=$ myristic acid, C16:0 =

Palmitic acid, $\mathrm{C} 18: 0=$ stearic acid, $\mathrm{C} 18: 1$ oleic acid, C18:2 linoleic acid, $\mathrm{C} 18: 3=$ linolenic acid, $\mathrm{C} 20: 2=$ arachidonic acid 
Table 3. Correlations between the parameters assessed with the first two principal components for Pulped Coffees and Natural Coffes

\begin{tabular}{llllll}
\hline \multirow{2}{*}{ Parameters } & \multicolumn{2}{c}{ Pulped Rank $(\mathrm{CD})$} & & \multicolumn{2}{c}{ Natural Rank (NAT) } \\
\cline { 2 - 3 } \cline { 5 - 6 } & PC1 & PC2 & & PC1 & PC2 \\
\cline { 2 - 3 } \cline { 5 - 6 } Sweetness & Correlation* & Correlation* & & Correlation* & Correlation* \\
Acidity & $\mathbf{- 0 . 8 2}$ & -0.40 & & $\mathbf{0 . 9 1}$ & -0.01 \\
Body & $\mathbf{- 0 . 8 1}$ & $\mathbf{- 0 . 5 1}$ & -0.34 & $\mathbf{0 . 7 6}$ & -0.49 \\
Flavor & $\mathbf{- 0 . 8 0}$ & -0.31 & & $\mathbf{0 . 6 5}$ & -0.21 \\
Final_Score & $\mathbf{- 0 . 8 4}$ & -0.39 & & $\mathbf{0 . 7 9}$ & -0.34 \\
C14:0 & $\mathbf{- 0 . 8 4}$ & $-\mathbf{0 . 4 9}$ & & -0.34 & -0.12 \\
C16:0 & -0.36 & -0.38 & -0.51 & 0.61 \\
C18:0 & -0.12 & 0.63 & & 0.48 & -0.31 \\
C18:1 & $\mathbf{- 0 . 7 6}$ & 0.78 & -0.51 & $\mathbf{- 0 . 7 9}$ \\
C18:2 & -0.35 & -0.45 & -0.34 & $\mathbf{- 0 . 6 4}$ \\
C18:3 & 0.79 & -0.32 & & 0.42 & 0.54 \\
C20:2 & 0.85 & 0.72 & 0.01 & 0.78 \\
\hline
\end{tabular}

Note. * Variables in bold and italic indicate groups of variables to be formed, characterized by variables whose correlation with the principal component are high and with the same signal.

\section{Discussion}

Many agronomic studies are conducted to differentiate coffee-producing sources, however little is known about the potential of the region of Matas de Minas, to produce specialty coffees. Our study showed that the specialty coffees of the region of Matas de Minas feature distinct and characteristic sensory profiles for the two processing categories evaluated. The attributes sweetness, acidity and flavor were important for the grouping of pulped coffees, while the body attribute was decisive for the grouping of natural coffees. From the PCA, it was possible to correlate the sensory attributes with the chemical composition of the grains, which had not yet been carried out with the coffees of the given region. The use of wet processing for the region of Matas de Minas is still the best option for specialty coffees, since these are still standing out and showing very balanced sensory profiles. Additional studies may be performed to improve results with larger sets of representative samples for each category.

\section{Acknowledgements}

The authors are grateful to the Empresa Mineira de Assistência Técnica Rural (EMATER), the Empresa de Pesquisa Agropecuária de Minas Gerais (EPAMIG), the Universidade Federal de Lavras (UFLA), the Agência de Inovação do Café (INOVACAFE), the Consórcio Pesquisa Café, the FAPEMIG and the CAPES.

\section{References}

Abreu, G. F., Pereira, C. C., Malta, M. R., Clemente, A. C. S., Coelho, L. F. S., \& Rosa, S. D. V. F. (2015). Alterações na coloração de grãos de café em função das operações pós-colheita. Coffee Science, 10(4), 429-436.

Alves, H. M. R., Volpato, M. M. L, Vieira, T. G. C., Borém, F. M., \& Barbosa, J. N. (2011). Características ambientais e qualidade da bebida dos cafés do estado de Minas Gerais. Informe Agropecuário, 32(261), $18-29$.

Amaral, J. S., Cunha, S. C., Santos, A., Alves, M. R., Seabra, R. M., \& Oliveira, B. P. P. (2006). Influence of Cultivar and Environmental Conditions on the Triacylglycerol Profile of Hazelnut (Corylus avellana L.). Journal of Agriculture and Food Chemistry, 54, 449-456. https://doi.org/10.1021/jf052133f

Avelino, J., Barboza, B., Araya, J. C., Fonseca, C., Davrieux, F., Guyot, B., et al. (2005). Effects of slope exposure, altitude and yield on coffee quality in two altitude terroirs of Costa Rica, Orosi and Santa María de Dota. Journal of the Science of Food Agriculture, 85, 1869-1876. https://doi.org/10.1002/jsfa.2188

Banks, J. M., Brechany, E. Y., \& Christie, W. (2007). The production of low fat Cheddar-type cheese. International Journal of Dairy Technology, 42, 6-9. https://doi.org/10.1111/j.1471-0307.1989.tb01699.x 
Barbosa, J. N., Borém, F. M., Alves, H. M. R., Volpato, M. M. L., Vieira, T. G. C., \& Souza, V. C. O. (2010). Spatial Distribution Of Coffees From Minas Gerais State And Their Relation With Quality. Coffee Science, 5(3), 237-250.

Barbosa, J. N., Borém, F. M., Cirillo, M. A., Malta, M. R., Alvarenga, A. A., \& Alves, H. M. R. (2012). Coffee Quality and Its Interactions with Environmental Factors in Minas Gerais, Brazil. Journal of Agricultural Science, 4(5), 181-190. https://doi.org/10.5539/jas.v4n5p181

Bertrand, B., Guyot, B., Anthony, F., \& Lashermes, P. (2003). Impact of the Coffea canephora gene introgression on beverage quality of C. arabica. Theoretical Applied Genetics, 107, 387-394. https://doi.org/10.1007/ s00122-003-1203-6

Bertrand, B., Vaast, P., Alpizar, E., Etienne, H., Davrieux, F., \& Charmetant, P. (2006). Comparison of bean biochemical composition and beverage quality of Arabica hybrids involving Sudanese-Ethiopian origins with traditional varieties at various elevations in Central America. Tree Physiology, 26, 1239-1248. https://doi.org/10.1093/treephys/26.9.1239

Bertrand, B., Villarreal, D., Laffargue, A., Posada, H., Lashermes, P., \& Dussert, S. (2008). Comparison of the effectiveness of fatty acids, chlorogenic acids, and elements for the chemometric discrimination of coffee (Coffea arabica L.) varieties and growing origins. Journal of Agriculture and Food Chemistry, 56, 2273-80. https://doi.org/10.1021/jf073314f

Borém, F. M., Coradi, P. C., Saath, R., \& Oliveira, J. A. (2008). Quality of natural and washes coffee after drying on ground and with temperature. Ciência e Agrotecnologia, 32(5), 1609-1615. https://doi.org/10.1590/ S1413-70542008000500038

Borém, F. M., Figueiredo, L. P., Ribeiro, F. C., Taveira, J. H. S., Giomo, G. S., \& Salva, T. J. G. (2016). The relationship between organic acids, sucrose and the quality of specialty coffees. African Journal of Agricultural Research, 11(8), 709-717. https://doi.org/10.5897/AJAR2015.10569

Brazil Speciality Coffee Association (BSCA). (2016). Cafés especiais. Retrieved July 15, 2016, from http://bsca.com.br/programa-cup-excellence.php

Buffo, R., \& Cardelli-Freire, C. (2004). Coffee flavour: an overview. Flavour and Fragrance Journal, 19(2), 99-104. https://doi.org/10.1002/ffj.1325

Campanha, M. M., Santos, R. H. S., Freitas, G. B., Martinez, H. E. P. M., Jaramillo-Botero, C., \& Garcia, S. L. (2007). Análise comparativa das características da serrapilheira e do solo em cafezais (Coffea arabica L.) cultivados em sistema agroflorestal e em monocultura, na Zona da Mata-MG. Revista Árvore, 31(5), 800-812. https://doi.org/10.1590/S0100-67622007000500004

Carvalho, A. M., Rezende, J. C., Rezende, T. T., Ferreira, A. D., Rezende, R. M., Mendes, A. N. G., \& Carvalho, G. R. (2016). Relationship between the sensoru atributes and the quality of coffee in different environments. African Journal of Agricultural Research, 11(18), 3607-3614. https://doi.org/10.5897/AJAR2016.11545

Carvalho, G. R., Rezende, J. C., Botelho, C. E., Ferreira, A. D., Pereira, A. A., \& Oliveira, A. C. B. (2011). Melhoramento genético do café visando à qualidade de bebida. Informe Agropecuário, 32(261), 30-38.

Clemente, A. C. S., Cirillo, M. A., Malta, M. R., Caixeta, F., Pereira, C. C., \& Rosa, S. D. V. F. (2015). Operações pós-colheita e qualidade físico-química e sensorial de cafés. Coffee Science, 10(2), 233-241.

Damodaran, S., Parkin, K., \& Fennema, O. R. (2007). Fennema's Food Chemistry (4th ed., p. 900). New York: CRC Press.

Decazy, F., Avelino, J., Guyot, B., Perriot, J. J., Pineda, C., \& Cilas, C. (2003). Quality of different Honduran coffee in relation to several environments. Journal of Food Science, 68, 2356-2361. https://doi.org/10.1111/ j.1365-2621.2003.tb05772.x

DonFrancesco, B. D., Guzman, G. N., \& Chambers, I. V. E. (2014). Comparison of results from cupping and descriptive sensory analysis of Colombian brewed coffee. Journal of Sensory Studies, 29, 301-311. https://doi.org/10.1111/joss.12104

Farah, A., Monteiro, M. C., Calado, V., Franca, A. S., \& Trugo, L. C. (2006). Correlation between cup quality and chemical attributes of Brazilian coffee. Food Chemistry, 98, 373-380. https://doi.org/10.1016/j.food chem.2005.07.032

Fassio, L. O. (2014). Potencial de novas cultivares de Coffea arabica L. resistentes à ferrugem para a produção de cafés especiais. Magister Scientiae, Universidade Federal de Lavras, Brazil. 
Fassio, L. O., Malta, M. R., Carvalho, G. R., Liska, G. R., Lima, P. M., \& Pimenta, C. J. (2016). Sensory Description of Cultivars (Coffea Arabica L.) Resistant to Rust and Its Correlation with Caffeine, Trigonelline, and Chlorogenic Acid Compounds. Beverage, 2(1), 1-12. https://doi.org/10.3390/beverages 2010001

Ferreira, W. P. M., Ferreira, G. R., Barbosa, T. K. M., Ribeiro, M. F., Filho, E. I. F., \& Rufino, J. L. (2016). Região Das Matas De Minas Tem Clima Ideal Para Produção De Café. Boletim Técnico: EPAMIG. Belo Horizonte.

Figueiredo, L. P., Borém, F. M., Cirillo, M. Â., Ribeiro, F. C., Giomo, G. S., \& Salva, T. D. J. G. (2013). The potential for high quality bourbon coffees from different environments. Journal of Agriculture Science, 5, 87-98. https://doi.org/10.5539/jas.v5n10p87

Figueiredo, L. P., Borém, F. M., Ribeiro, F. C., Giomo, G. S., Taveira, J. H. S., \& Malta, M. R. (2015). Fatty acid profiles and parameters of quality of specialty coffees produced in different Brazilian regions. African Journal of Agricultural Research, 10(35), 3484-3493. https://doi.org/10.5897/AJAR2015.9697

Folch, J., Lees, M., \& Stanley, G. H. S. (1957). A simple method for the isolation and purification of total lipids from animal tissues. Journal of Biological Chemistry, 226, 497-509.

Franca, A. S., Mendonça, J. C. F., \& Oliveira, S. D. (2005). Composition of green and roasted coffees of different cup qualities. LWT-Food Science and Technology, 38(7), 709-715. https://doi.org/10.1016/j.lwt. 2004.08.014

Illy, A., \& Viani, R. (2005). Espresso coffee: The chemistry of quality (p. 398). London: Academic Press.

Jham, G. N., Berhow, M. A., Manthey, L. K., Palmquist, D. A., \& Vaughn, S. F. (2008). The use of fatty acid profile as a potential marker for Brazilian coffee (Coffea arabica L.) for corn adulteration. Journal of the Brazilian Chemical Society, 19, 1462-1467. https://doi.org/10.1590/S0103-50532008000800004

Knopp, S. E., Bytof, G., \& Selmar, D. (2006). Influence of processing on the content of sugars in green arabica coffee beans. European Food Research and Technology, 223(2), 195-201. https://doi.org/10.1007/s00217005-0172-1

Lingle, R. T. (2011). The coffee cupper's handbook: Systematic guide to the sensory evaluation of coffee's flavor. (4th ed.). Long Beach: SCAA.

Link, J. V., Lemes, A. L. G., Marquetti, I., Scholz, M. B. S., \& Bona, E. (2014). Geographical and genotypic segmentation of arabica coffee using self-organizing maps. Food Research International, 59, 1-7. https://doi.org/10.1016/j.foodres.2014.01.063

Liska, G. R., Menezes, F. S., Cirillo, M. A., Borém, F. M., Cortez, R. M., \& Ribeiro, D. E. (2015). Evaluation of sensory panels of consumers of specialty coffee beverages using the boosting method in discriminant analysis. Semina: Ciências Agrárias, 36(6), 3671-3680. https://doi.org/10.5433/1679-0359.2015v36n6p 3671

Malta, M. R., \& Chagas, S. J. R. (2009). Avaliação de compostos não-voláteis em diferentes cultivares de cafeeiro produzidas na região Sul de Minas Gerais. Acta Scientiarum Agronomy, 31, 57-61. https://doi.org/10.4025/actasciagron.v31i1.6629

Malta, M. R., Rosa, S. D. V. F., Lima, P. M., Fassio, L. O., \& Santos, J. B. (2013). Alterações na qualidade do café submetido a diferentes formas de processamento e secagem. Engenharia na Agricultura, 21(5), 431-440. https://doi.org/10.13083/1414-3984.v21n05a01

Martín, M. J., Pablos, F., González, G., Valdenebro, M. S., \& Léon-Camacho, M. (2001). Fatty acid profile as discriminant parameters for coffee varieties differentiation. Talanta, 54(2), 291-297. https://doi.org/10.1016/ S0039-9140(00)00647-0

Mendonça, J. C. F., Franca, A. S., \& Oliveira, L. S. (2009). Physical characterization of non-defective and defective Arabica and Robusta coffees before and after roasting. Journal of Food Engineering, 92(4), 474-479. https://doi.org/10.1016/j.jfoodeng.2008.12.023

Morlat, R., \& Bodin, F. (2006). Characterization of Viticultural Terroirs using a Simple Field Model Based on Soil Depth-II. Validation of the Grape Yield and Berry Quality in the Anjou Vineyard (France). Plant and Soil, 281(1), 55-69. https://doi.org/10.1007/s11104-005-3769-z

Murkovic, M., \& Derler, K. (2006). Analysis of amino acids and carbohydrates in green coffee. Journal Biochemical Biophysical Methods, 69, 25-32. https://doi.org/10.1016/j.jbbm.2006.02.001 
Oestreich-Janzen, S. (2010). Chemistry of coffee. Comprehensive Natural Products, II(3), 1085-1117. https://doi.org/10.1016/B978-008045382-8.00708-5

Oosterveld, A., Voragen, A. G. J., \& Schols, H. A. (2003). Effect of roasting on the carbohydrate composition of Coffea arabica beans. Carbohydrate Polymers, 54(2), 183-192. https://doi.org/10.1016/S0144-8617(03) 00164-4

Perrone, D., Farah, A., \& Donangelo, C. M. (2012). Influence of coffee roasting on the incorporation of phenolic compounds into melanoidins and their relationship with antioxidant activity of the brew. Journal of Agriculture and Food Chemistry, 60, 4265-4275. https://doi.org/10.1021/jf205388x

Piccino, S., Boulanger, R., Descroix, F., \& Sing, A. S. C. (2014). Aromatic composition and potent odorants of the "specialty coffee" brew "Bourbon Pointu" correlated to its three classifications. Food Research International, 61, 264-271. https://doi.org/10.1016/j.foodres.2013.07.034

R Development Core Team. (2013). R: A language and enviroment for statiscal computing. Vienna: Foundation for Statiscal Computing. Retirieved October 20, 2016, from http://www.R-project.org

Ramos, M. F., Ribeiro, D. E., Cirillo, M. A., \& Borém, F. M. (2016). Discrimination of the sensory quality of the Coffea arabica L. (cv. Yellow Bourbon) produced in different altitudes using decision trees obtained by the CHAID method. Journal of the Science of Food and Agriculture, 96, 3543-3551. https://doi.org/10.1002/ jsfa.7539

Ribeiro, D. E., Borém, F. M., Cirillo, M. A., Prado, M. V. B., Ferraz, V. P., Alves, H. M. R. A., \& Taveira, J. H. S. (2016). Interaction of genotype, environment and procesing in the chemical composition expression and sensorial quality of Arabica coffee. African Journal Agriculture Research, 11(27), 2412-2422. https://doi.org/10.5897/AJAR2016.10832

Ribeiro, J. S., Augusto, F., Salva, T. J., Thomaziello, R. A., \& Ferreira, M. M. (2009). Prediction of sensory properties of Brazilian Arabica roasted coffees by headspace solid phase microextraction-gas chromatography and partial least squares. Analytica Chimica Acta, 364(2), 172-179. https://oi.org/10.1016/ j.aca.2008.12.028

Scholz, M. B., Dos, S., Silva, J. V. N., Figueiredo, V. R. G., \& Kitzberger, C. S. N. (2013). Atributos sensoriais e características físico-químicas de bebida de cultivares de café do IAPAR. Coffee Science, 8(1), 6-16.

Scolforo, J. R., Carvalho, L. M. T., \& Oliveira, A. D. (2007). ZEE-Zoneamento Ecológico Econômico de Minas Gerais. Lavras: Editora UFLA.

Silva, S. A., Queiroz, D. M., Ferreira, W. P. M., Corrêa, P. C., \& Rufino, J. L. S. (2016). Mapping the potential beverage quality of coffee produced in the Zona da Mata, Minas Gerais, Brazil. Journal of the Science of Food and Agriculture, 96, 3098-3108. https://doi.org/10.1002/jsfa.7485

Silva, S. A., Queiroz, D. M., Pinto, F. A. C., \& Santos, N. T. (2014). Characterization and delimitation of the terroir coffee in plantations in the municipal district of Araponga, Minas Gerais, Brazil. Revista Ciência Agronômica, 45(1), 18-26. https://doi.org/10.1590/S1806-66902014000100003

Silveira, A. S., Pinheiro, A. C. T., Ferreira, W. P. M., Silva, L. J., Rufino, J. L. S., \& Sakiyama, N. S. (2016). Sensory analysis of specialty coffee from different environmental conditions in the region of Matas de Minas, Minas Gerais, Brazil. Revista Ceres, 63(4), 436-443. https://doi.org/10.1590/0034-737X2016630 40002

Sobreira, F. M., Oliveira, A. C. B., Pereira, A. A., Sobreira, M. F. C., \& Sakyiama, N. S. (2015). Sensory quality of arabica coffee (Coffea arabica) genealogic groups using the sensogram and content analysis. Australian Journal of Crop Science, 9(6), 486-493.

Specialty of Coffee Association of America. (2015). SCAA protocols cupping specialty coffee. Retrieved December 10, 2016, from http://scaa.org/PDF/resources/cupping-protocols.pdf

Sunarharum, W. B., Williams, D. J., \& Smyth, H. E. (2014). Complexity of coffee flavor: A composition and sensory perspective. Food Research International, 62, 315-325. https://doi.org/10.1016/j.foodres.2014. 02.030 


\section{Copyrights}

Copyright for this article is retained by the author(s), with first publication rights granted to the journal.

This is an open-access article distributed under the terms and conditions of the Creative Commons Attribution license (http://creativecommons.org/licenses/by/4.0/). 